\title{
AKTIVISME TASAWUF MENURUT FETHULLAH GÜLEN
}

\author{
Anang Haderi \\ Forum Studi Islam dan Sosial (FoSIS) \\ Alumni Universitas Antakusuma (UNTAMA) Pangkalan Bun, Kalimantan Tengah \\ e-mail: rysagaj@yahoo.com
}

\begin{abstract}
This article will elaborate the sufism thought of Fethullah Gulen. He has transformed Sufism from purely spiritual experience turned into an activity that is directly in contact with the issue of Muslims and human beings on this earth. Two of the most prominent organizer of the mystical transformation is education and the world peace movement. He tried to bring peace to the world across cultures, religions and ethnicities. The thought pattern of Gülen which is based on religious values and the universality has created a concept which is more popular in the community, but do not abandon spiritual values. The transformation of ideas and concepts of sufism who taught the importance of devotion to others, selflessness and love of neighbor.
\end{abstract}

Abstrak: Artikel ini akan mengelaborasi pemikiran tasawuf Fethullah Gulen. Ia telah mentransformasikan tasawuf dari yang hanya bersifat pengalaman spiritual berubah menjadi sebuah aktivitas yang langsung bersentuhan dengan persoalan umat Islam dan manusia di bumi ini. Dua agenda yang paling menonjol dari transformasi sufistiknya itu adalah pendidikan dan gerakan perdamaian dunia. Ia berupaya mewujudkan perdamaian dunia lintas budaya, agama maupun etnis. Pola pemikiran Gülen yang dilandasi nilai-nilai keagamaan dan universalitas telah menciptakan konsep yang lebih memasyarakat namun tidak meninggalkan nilai-nilai spiritual. Transformasi dari pemikiran dan konsep tasawwuf yang mengajarkan pentingnya pengabdian kepada orang lain, tidak mementingkan diri sendiri dan cinta terhadap sesama.

Keywords: transformasi, tasawuf, perdamaian, pendidikan, generasi emas. 


\section{A. Pendahuluan}

Fethullah Gülen dilahirkan ketika kondisi Turki sedang berada dalam suasana yang tidak stabil, kelahiran Gülen disambut dengan kejadian besar di Turki, yaitu memudarnya kekuasaan Kekhalifahan Usmaniyah akibat mengalami kekalahan dari Sekutu pada perang dunia I. Kekalahan Turki Usmani ternyata membawa pengaruh yang besar bagi perubahan tata perpolitikan di Turki, yang pada akhirnya membawa Turki menjadi negara Republik modern di bawah pemimpin Mustafa Kemal Attaturk (1922). Naiknya Mustafa Kemal Attaturk menjadi pemimpin Turki memberikan banyak perubahan bagi kehidupan masyarakat pada waktu itu, setidaknya ada beberapa perubahan besar yang dilakukannnya, antara lain, membubarkan kesultanan (1922); memproklamasikan berdirinya Republik Turki (1923); menghapus kekhalifahan, membubarkan Kementerian Agama, menutup sekolah agama dan pengadilan agama (1924); memberangus perkumpulan-perkumpulan sufi dan membongkar kuburan para wali; menerapkan Hukum Sipil menggantikan hukum syariah (1926), mengubah huruf arab dengan tulisan latin (1928). ${ }^{1}$

Perubahan di Turki membawa perubahan pada kondisi spiritual dan material masyarakat Turki secara langsung dan Umat muslim di seluruh dunia secara tidak langsung. Kehidupan spiritual telah tereliminasi dari kehidupan masyarakat dan digantikan oleh meningkatnya budaya material, orang

${ }^{1}$ Ali Unal dan Alphonse Williams, $A d-$ vocate of Dialogue: Fethullah Gulen. 2000, Fairfax: The Fountain, h. 9. lebih mementingkan modernitas daripada nilai-nilai tradisional, lebih memilih menggunakan rasio daripada wahyu agama dan yang terpenting, orang-orang tidak lagi menggunakan hati dalam bertindak namun cenderung lebih memilih kekuatan akal pikiran. ${ }^{2}$

Kondisi ini menyebabkan banyak orang lebih mementingkan diri sendiri dan cenderung apatis terhadap orangorang di sekitarnya. Selain itu, kondisi umat Islam di berbagai belahan dunia juga menimbulkan keprihatinan mendalam bagi Fethullah Gülen, ia menyadari bahwa banyaknya penindasan, konflik berkepanjangan dan peperangan tidak akan bisa terselesaikan jika setiap orang masih memunculkan egonya sendiri, oleh karena itu dunia membutuhkan seorang yang mampu menjadi penengah untuk menyelesaikan konflik-konflik tersebut.

Pengalaman spritual Fethullah Gülen sangat paradoks dengan kondisi sosial yang sedang terjadi di masyara-kat. Ia merupakan pribadi yang banyak belajar dari sosok Said Nursi, Jalaludin Rumi dan tokoh-tokoh sufi lainnya sehingga karakter spiritualnya banyak dipengaruhi oleh ajaran-ajaran tasawuf yang menekankan pada taqwa, taubat, zuhud, ikhlas, muraqaba, istiqamah, tawakkal, tawadu', syukur, ihsan, sabar, dan ma'r ifah. Ajaran-ajaran Tasawuf yang diterimanya, menekankan sifat toleransi dan kepedulian dalam diri Fethullah Gülen, demi memenuhi pergolakan batinnya dan keprihatinannya terhadap kondisi masyarakat maka ia mencoba untuk menyumbangkan pemi-

${ }^{2}$ A. Rizqon Khamami, "Islam Kosmopolitan Dalam Ajaran-ajaran Fethullah Gülen", Jurnal Al-Fikr, Volume 15 Nomor 2 Tahun 2011. 
kirannya sebagai bentuk kepedulian dan pengabdian kepada masyarakat (hizmet).

\section{B. Tentang Fethullah Gülen}

Fethullah Gulen lahir pada tahun 1938 di sebuah kota kecil yang dihuni oleh sekitar 50-60 kepala keluarga di Korucuk, Propinsi Erzurum. ${ }^{3}$ Kelahiran Gulen bersamaan dengan kejadian besar yang tengah berlangsung di Turki: Kekhalifahan Usmaniyah kalah dalam Perang Dunia I, lalu diubah oleh Mustafa Kemal Attaturk menjadi republik modern yang kita kenal dengan Turki modern. Mempercepat usaha ini, Attaturk mengadakan beberapa revolusi: membubarkan kesultanan (1922); memproklamasikan berdirinya Republik Turki (1923); menghapus kekhalifahan, membubarkan Kementerian Agama, menutup sekolah agama dan pengadilan agama (1924); memberangus perkumpulan-perkumpulan sufi dan membongkar kuburan para wali; menerapkan Hukum Sipil menggantikan hukum syariah (1926), mengubah huruf arab dengan tulisan latin (1928). ${ }^{4}$

Selain sebagai seorang pegiat dialog antaragama, Fethullah Gulen adalah seorang penulis yang produktif. Ia menulis tidak kurang 60 buku, video dan tape yang berisi ceramahnya. ${ }^{5}$ Ia

${ }^{1}$ Ali Unal and Alphonse Williams, Advocate of Dialogue: Fethullah Gulen. 2000, Fairfax: The Fountain, h.9.

${ }^{4}$ Ibid., h. ii.

5M. Amin Abdullah: Muslim-Christian Relations: Reinventing the Common Ground to Sustain a Peaceful Coexistence in the Global Era. Draft paper yang disampaikan di the International Seminar on "The Vision of Fethullah Gulen and Muslim-Christian Relations", St. Patrick's Campus, Australian Catholic University, Melbourne, Australia, 15-16 Juli 2009. menjadi inspirasi bagi jutaan orang. Pemujanya dapat kita dapati di lebih dari 100 negara di dunia. Mereka ikut mendirikan ratusan institusi pendidikan. Sebagian sarjana menyebutnya sebagai "the Fethullah Gulen Movement" (Gerakan Fethullah Gulen), sedangkan para pegiat gerakan ini menyebutnya sebagai hizmet, kata Turki yang berasal dari kata khidmah, pelayanan.

Pemikiran Gulen tentang hizmet didasarkan pada ajaran Islam. Gulen menandaskan bahwa kesalehan (piety) adalah dengan 'berbuat' dan 'bekerja' (to work), bekerja untuk melayani umat manusia. Iman, bagi Gulen, adalah applied action, tidak hanya berhenti sebagai keyakinan semata. Etos agama Islam adalah hizmet, pelayanan. Agama, dengan demikian, ia ditransformasikan menjadi pelayanan kepada umat manusia. Dengan jumlah pengikut besar dan jutaan simpatisan, menjadikan gerakan ini sebagai gerakan sipil terbesar. ${ }^{6}$

Gulen adalah seorang pemimpin spiritual, ahli agama, intelektual, aktivis perdamaian, penulis, sastrawan, dan seorang mentor yang menghabiskan hidupnya mencari penyelesaian tentang kebutuhan akan spiritual pada masyarakat Muslim modern. ${ }^{7}$ Banyak ide Gulen dipengaruhi oleh Said Nursi (18761960), yang menulis "Risale-i Nur Kulliyati" atau "Risalah tentang Cahaya Alam". Tokoh lain yang ikut mempengaruhi pemikiran Gulen adalah Alvarli

${ }^{6}$ Yavuz and Esposito, Turkish Islam and the Secular State: the Gulen Movement. Edited by M. H. Yavuz and J. L. Esposito Syracuse: Syracuse University Press, h. xiii.

${ }^{7}$ Yilmaz, "State, Law, Civil Society, and Islam in Contemporary Society". The Muslim World 95, 3. 
Muhammad Lutfi, seorang tokoh sufi, Mehmet Akif, seorang penyair Turki, Necip Fazil, tokoh intelektual Turki dan sekaligus penyair, dan Muhammed Hamdi Yazir (1878-1942), seorang mufasir al-Quran. ${ }^{8}$ Ozdalga mengungkapkan bahwa aliran Islam sunni, terutama tradisi sufi Naqshabandi, dan Nurculuk ${ }^{11}$ (Gerakan Nur) telah membentuk pemikiran Fethullah Gulen. ${ }^{9}$

Gulen belajar di bawah bimbingan Muhammad Lutfi dalam agama. Sementara itu, Gulen juga belajar bahasa Arab dari Sadi Efendi, dan belajar al-Quran dari al-Qari Haci Sidqi Efendi. Pada umur 7 tahun ia menjadi seorang penghafal al-Quran. Selama 1950-an ia mempelajari teori-teori sosial modern dan sains fisika. Gulen belajar hadis dengan mempelajari kutub al-sittah (Bukhari, Muslim, Nasai, Ibn Majah, Tirmiżi, dan Abu Dawud). Selain itu, ia juga mempelajari khitabah, filsafat, sejarah Islam, teologi, dan fiqh. Ia juga mempelajari karya-karya filosof klasik dan modern seperti Aristoteles, Marcus, Descartes, Kant, Camus, dan Sartre. ${ }^{10}$

Satu titik penting dalam hidup Gulen adalah pertemuannya dengan salah seorang murid Said Nursi (yang mengantarkannya membaca Risail-i Nur). ${ }^{11}$ Gulen sangat terinspirasi oleh kehidupan spiritual Nursi dan sema-

${ }^{8}$ Kraus, Civility in Islamic Activism: Toward a Better Understanding of Shared Values for Civil Society Development, h. 165.

${ }^{9} \mathrm{M}$. Elizabeth Ozdalga, Worldly Asceticism in Islamic Casting: Fethullah Gulen's Inspired Piety and Activism, h. 91.

${ }^{10}$ Ali Unal and Alphonse Williams, Advocate, h. 16. Lihat Salih Yucil, "Fethullah Gulen: Spiritual Leader in a Global Islamic Context", Journal of Religion \& Society, The Kripke Center. Volume 12 (2010), h. 2.

11 Ibid., h. 15. ngatnya melayani umat. Kelak ia menerapkan ajaran Nursi itu dalam prinsip hizmet. Keberhasilan dan kesuksesan terbesar Gulen adalah mendidik generasi muda dalam ilmu-ilmu sains dan agama sehingga mampu mengentaskan mereka dari kejahilan dan membentengi mereka dari penyakit-penyakit spiritual.

Pada bulan Maret 1972, saat kudeta militer, Gulen ditangkap dan ditahan selama empat bulan. Di kemudian hari diketahui bahwa pihak militer memenjarakan beberapa tokoh agama bersama-sama dengan aktivis komunis dan kiri untuk memperlihatkan kepada publik bahwa pemimpin militer tidak saja menentang komunis tapi juga kelompok lain. Setelah Gulen dilepaskan, ia terus berdakwah hingga terjadi kudeta militer kedua pada tahun 1980.12

Bagi mereka yang mengaguminya, ajaran Gulen menjadi inspirasi pendirian Gulen Movement (gerakan Gulen), yang dinamakan "Fethullahcilar" (Pengikut Fethullah) oleh kelompok kiri, dan "Nurcu" (gerakan Penerangan) oleh kelompok tradisionalis dan konservatif. Gulen sendiri tidak setuju penggunaan nama dirinya dalam gerakan itu.

Kendati adanya paksaan dari ibunya dan dorongan teman-teman dekatnya, Gulen memilih untuk tidak menikah. Ketika ditanya tentang istri, ia menjawab sebagaimana jawaban Said Nursi (1878-1960), "Penderitaan yang dialami oleh masyarakat Muslim lebih

12Turki mengalami tiga kali kudeta militer. Gulen secara tak langsung mengkritik kudeta tersebut karena tidak sedikit korban jiwa yang melayang. Sikap ini ia tuangkan dalam artikel "On Recent Terrorist Attack" yang merupakan hasil wawancara Gulen dengan Nuriye Akman, diterbitkan dalam Zaman antara 22 Maret-1 April 2004 (Toward a Global Civilization of Love and Tolerance, h.189). 
dari cukup. Sampai-sampai saya tidak menemukan waktu untuk memikirkan diri saya sendiri."13 Kendati begitu, Gulen adalah seorang muslim yang taat. Professor Suat Yildirim, mantan Dekan the School of Divinity di Sakarya, murid dan teman dekat Fethullah Gulen mengungkapkan tentang kesalehannya:

"I have known Gulen since he was an imam in Edirne at the beginning of 1959. He is very intellectual and devoted to education. He read Eastern and Western classics. This is Gulen's defining characteristic that set him apart from the contemporary imams and religious leaders. With a greater part of his salary, he would buy books and journals, read them, and then give them to others to read. He would spend a portion of his time daily in Edirne's library, where he would read old history books. He had and still has an ascetic life; he would eat little, sleep only a few hours, and spent a great part of his day in worship."14

Dr. Ismail Buyukcelebi, salah satu teman dekat Gulen selama hampir empat puluh tahun bercerita:

"I have been with Gulen since middle school. He used to preach in Izmir and teach my peers and I at Kestane Pazari Qur'anic boarding school. He would not only teach us, but also mentored us. He himself would live in a closet-sized room next to the school building. He lived a very simple life and spent most of his salary providing for the poor students. He would spend his effort in worship and

${ }^{13}$ Salih Yucel, "Fethullah Gulen: Spiritual Leader in a Global Islamic Context", Journal of Religion \& Society, The Kripke Center. Volume 12 (2010), h. 3.

${ }^{14}$ Ibid., h. 3. education and avoid meaningless or fruitless activities and politics."15

Setiap kali mengajar, Gulen lebih memusatkan pada cinta, iman, dan sunnah Nabi. Selain itu ia juga menjelaskan tentang penyucian diri, kriteria dan prinsip dasar hizmet, melayani masyarakat, konsep kunci tasawuf seperti taqwa, taubat, zuhud, ikhlas, muraqaba, istiqamah, tawakkal, tawadu', syukur, ihsan, sabar, dan ma'rifah. Cinta, tulis Gulen, adalah elemen paling penting bagi setiap makhluk hidup, dan.cinta juga yang bisa mengangkat martabat seseorang dan mempersiapkan jiwanya menuju keabadian. Kekuatan cinta ini diceritakan oleh Gulen sebagai penggerak segala sesuatu, termasuk perputaran alam semesta. Bahkan matahari sendiri, ungkap Gulen, bergerak dan digerakkan oleh cinta; air menguap, menuju cinta itu, lalu menjadi butiranbutiran air di atas sana dan berjatuhan ke atas permukaan bumi dibawa oleh sayap cinta, lantas ribuan bunga mekar berkat cinta menawarkan senyum indah kepada apa yang di sekitarnya. Domba dan kambing meloncat berlarian dalam riang dan cinta, dan burung berkicau bersama cinta dan membentuk paduan suara penuh cinta. $^{20}$ Karena itu, cinta menjadi dasar penting seorang Muslim dalam interaksinya dengan kelompok lain, dan nilai dasar dari masyarat sesungguhnya adalah cinta,

"In society, if there is a currency that maintains its value, it is love, and again the value of love is found itself."16

\footnotetext{
15 Ibid., h. 3.

${ }^{16}$ M. Fethullah Gulen, Toward, h. 5.
} 


\section{Aktivisme Tasawuf}

Pembaharuan signifikan Gülen dan hubungannya dengan Tasawwuf menekankan pada aksi sosial kultural dan bahkan tindakan politik yang sama pentingnya dengan keyakinan bahwa perdamaian hanya dapat dicapai jika didukung oleh tindakan-tindakan tersebut. Tindakan nyata dari setiap orang bisa berupa aksi sosial seperti, melibatkan diri dalam komunitas, berbagi pengalaman kepada orang lain, bekerja keras untuk menolong orang lain dan membawa perdamaian bagi seluruh masyarakat dunia. ${ }^{17}$

Manifestasi dari aktivisme tasawuf Fethullah Gülen dapat dipilah dalam tiga kategori yang kemudian menjadi model gerakannya: (1) terlibat dalam perdamaian dunia dan (2) pendidikan.

\section{C.1. Perdamaian Dunia}

Ajaran Rumi yang mengilhami pemikiran Gülen mengajarkan tentang keharmonisan, keselarasan dan kerendahan hati antara sesama manusia. Ajaran Rumi ini termanifestasi dalam gerakan tarian darwis yang merupakan simbol dari cara hidup untuk memaknai zikir ilahi dalam Islam yang dianggap sebagai ibadah tertinggi dari semua aktivitas manusia. Dalam konteks pemahaman terhadap keharmonisan manusia dengan manusia dan manusia dengan alam, gerakan-gerakan berputar tersebut merupakan sumber inspirasi bagi orang-orang yang menginginkan terciptanya perdamaian dan kasih sayang

17Ihsan Yilmaz, "Tajdid For Coexistence: Social Innovation And Activism Socio-Cultural Initiatives For Peace From Rumi and Gülen ," dalam Peaceful Coexistence: Fethullah Gülen 's Initiatives in the Contemporary World, New Jersey: TUGHRAH BOOKS, 2009, h. 6. antara sesama manusia melalui Tarian Darwis ini pula, para ahli menafsirkan bahwa Rumi menyelipkan pesan perdamaian dalam tariannya. Professor Majid M. Naini mengatakan bahwa kehidupan dan transformasi Rumi telah memberikan bukti bahwa orang-orang dari berbagai latar belakang dan agama dapat hidup bersama dalam damai dan harmoni. ${ }^{18}$

Secara implisit kita bisa melihat bahwa Rumi dan ajarannya dianggap mendukung penuh rasa toleransi, penalaran, kebaikan, amal dan kesadaran melalui cinta yang selama ini diakui merupakan ajaran yang dimiliki oleh setiap agama yang ada, baik Islam, Yahudi, Kristen, dan lain-lain. ${ }^{19}$ Melalui ajaran Rumi ini kita bisa melihat refleksi Gülen dalam mewujudkan perdamaian dengan lebih sederhana. Ia meyakini bahwa dalam kebersamaan kita dalam menjalani kehidupan ini adalah panggilan untuk mewujudkan kehidupan yang damai, saling menghargai dan saling mengasihi. Ini bisa ditemukan dari tulisan-tulisan dan karya-karyanya yang jumlahnya ratusan buah dan sebagian besar dari karya-karyanya tersebut berisikan interpretasi dari teks-teks suci Islam yang meletakkan dasar untuk bekerja keras, pengampunan dan tidak mementingkan diri sendiri.

Melalui ajaran Tasawuf inilah, Gülen kemudian menjadi sosok bijaksana yang berupaya memahami setiap perilaku manusia yang cenderung anarkhis, self centric, bahkan mengarah ke-

18Ibid., h. 2.

${ }^{19}$ Muhammad Zaairul Haq, Jalaluddin Rumi: Terbang menuju Keabadian Cinta hingga Makna dibalik Kisah, Sidorejo: Kreasi Wacana, 2011. 
pada sifat-sifat vandalisme. Untuk mewujudkan cita-cita besarnya tersebut, Gülen membentuk sebuah komunitas yang bisa mendukung dan menopang perjuangannya, komunitas ini pun kemudian berevolusi menjadi sekumpulan orang-orang yang cinta terhadap perdamaian. Mereka berprinsip bahwa "Kami tidak ingin perang, kami tidak ingin konflik". Gülen mendorong pengikutnya untuk menghormati dan menerima pendapat dan keyakinan organisasi dan individu yang berbeda. Ia mengatakan, "Perbedaan adalah bagian terindah hidup manusia". Ungkapan ini juga didasarkan atas pandangan Bediuzzaman Said Nursi, "We are devotees of love; we do not have time for antagonism."20 Muslim sejati, ujar Gülen, adalah wakil perdamaian universal yang paling dapat dipercaya. ${ }^{21}$ Melalui segala upaya yang telah dilakukannya, Gülen merumuskan resolusi yang tepat untuk menciptakan perdamaian di antara umat manusia di dunia.

\section{C.2. Pendidikan}

Gulen mendefinisikan pendidikan sebagai proses penyempurnaan dalam hidup yang dengannya kita bisa meraih dimensi spiritual, intelektual dan fisikal kemanusiaan. Baginya, pendidikan adalah tugas Ilahiyah yang hanya dengan itulah kita bisa merasakan esensi kemanusiaan. Pendidikan dalam perspektif Gulen adalah "Special Service" yang menjadi tugas kolektif berbasis komunitas. Hal ini disebabkan pandangannya bahwa tujuan hidup terletak pada kebaikan (baca: berbuat baik) yang dilakukan

${ }^{20}$ Fethullah, Gülen. Towards a Global Civilization of Love and Tolerance, Clifton: Light Publications, 2004, h.91.

21Ibid., h. 90. secara bersama-sama. Pandangan Gulen tentang pendidikan dengan demikian tersimpul dan terkait erat dengan sisi keimanannya (fully-integrated with his belief). ${ }^{22}$

Dalam sebuah pernyataannya, Gulen berkata: "We are only truly human if we learn, teach and inspire others". Kita menjadi manusia hanya karena kita belajar, mendidik dan menginspirasi orang lain. Esensi kemanusian kita dengan demikian bukanlah akal, otak ataupun pikiran, tetapi penggunaan akal agar berguna dan bermanfaat buat orang lain. Pendidikan berbanding lurus dan sederajat dengan kemanusiaan kita. Gulen sering membandingkan manusia dengan hewan dalam soal pendidikan. Hewan hanya dalam hitungan hari bisa mendapatkan kemampuan untuk digunakan seumur hidupnya. Sementara manusia memerlukan puluhan tahun untuk menjadi manusia yang sesungguhnya dan mengenal Tuhannya. Bahkan ada manusia yang hingga akhir hayatnya belum mendapatkan bekal kehidupannya. ${ }^{23}$

Seorang murid langsung Gulen, Dr. Ali Unsal, memberikan gambaran visi pendidikan Gulen sebagai berikut:

Gülen sebagai pelopor pendidikan Turki yang mensinergikan antara pendidikan moral dengan ilmu-ilmu eksak dan kekinian, telah berhasil membangun dan menciptakan generasigenerasi baru yang tak hanya cerdas dalam sains dan teknologi, namun juga memiliki kepekaan sosial yang

${ }^{22}$ Ali Sahin, Pemikiran M. Fethullah Gulen Dalam Pendidikan Islam, Skripsi pada Jurusan Pendidikan Agama Islam FITK UIN Syarif Hidayatullah Jakarta, 2014, h. 20.

23Ibid., h. 21. 
tinggi karena ditempa moralitas yang luhur. ${ }^{24}$

Melalui pendidikan inilah Gulen berkeyakinan akan menghasilkan manusia yang bisa menghargai sesama makhluk Tuhan. Salah satu tujuan utama dari Gulen adalah untuk mencapai nilai-nilai universal dan ia percaya hal ini menjadi penting untuk pengalaman manusia. Ia percaya bahwa pendidikan, cinta, saling menghormati, dan filantropi adalah satu-satunya pendekatan untuk membangun perdamaian dan harmoni di antara umat manusia. Jadi, salah satu faktor penting dalam meminimalkan konflik adalah menghormati umat manusia. Ini hanya dapat dicapai melalui informasi, interaksi, dan saling pengertian. Oleh karena itu, Gulen pertama kali menyebarkan filsafat pendidikan di Turki dan dia ingin para pendukungnya untuk mengajarkan dan mengaplikasikan ke daerah lain di seluruh dunia. Bagi Gulen, sekolah harus menjadi salah satu tempat untuk mendapatkan cinta, belas kasih, dan pengajaran secara sepenuh hati melalui contoh dengan referensi khusus untuk memberikan nilai-nilai kemanusiaan serta moral yang baik bagi pelajar. Bagi Gulen, solusi untuk memerangi kebodohan adalah melalui pendidikan, sedangkan untuk mengakhiri kemiskinan dan perpecahan adalah melalui dialog, saling pengertian, dan kerjasama. Dan ini sangat sejalan dengan visi perdamaian yang diusungnya sebagaimana diuraikan di atas.

Visi perdamaian yang dimotori oleh Gülen merupakan sebuah rencana

${ }^{24}$ Ali Unsal, "Model Pendidikan Gulen", makalah disampaikan di International Conference on Indonesian Studies, Bali, 9 Pebruari 2012. jangka panjang yang mulai digerakkan saat ini. Melalui pembangunan berbagai institusi pendidikan di seluruh dunia, Gülen ingin mengarahkan generasi muda menuju cita-cita perdamaian universal tanpa memandang status agama, etnis maupun batas geografis suatu negara. Gülen sangat menyadari bahwa masa depan perdamaian terletak di pundak para generasi muda. Oleh karena itu mereka yang ingin melihat masa depan yang lebih damai harus mencurahkan setiap tenaganya untuk mendidik para generasi mudanya.

Pemuda tidak boleh dipengaruhi oleh prilaku-prilaku yang tidak sesuai dengan syariat Islam, karena itu akan menjauhkannya dari Tuhan, pemuda tidak boleh dibimbing dengan kekerasan, karena itu akan membuatnya menjadi generasi yang keras, pemuda harus dididik dengan kasih sayang karena itu akan melahirkan generasi-generasi yang cinta akan perdamaian.

Gülen sangat menekankan pendidikan sebagai bagian dari gerakan pembaharuan yang diusungnya. Saat ini sudah ada 200 lebih institusi pendidikan yang menggunakan model pendidikan Gülen di seluruh dunia, mulai dari Cina sampai sampai Amerika, dari Australia hingga Eropa. Melihat perkembangan gerakan ini yang begitu pesat, penulis bisa melihat Gülen sebagai sosok yang visioner, yang memimpikan sebuah perubahan yang tidak hanya bisa di capai dalam satu atau dua generasi saja, melainkan banyak generasi, oleh karena itu pendidikan adalah salah satu cara yang paling efektif untuk mewujudkan itu.

Tak pelak lagi, pendidikan merupakan media pembentuk karakter yang 
paling baik. Pendidikan bisa didapatkan di mana saja, seorang anak bisa memperoleh pendidikan di rumah, di sekolah, di tempat pergaulan dan di alam. Seorang anak akan mendapatkan pendidikan yang baik di rumah jika anggota keluarga memiliki kehidupan yang baik, di mana seorang yang lebih tua harus memperlakukan yang lebih muda dengan penuh kasih sayang, sedangkan yang muda harus memperlihatkan rasa hormat kepada yang lebih tua. Melalui model pendidikan di keluarga seorang anak akan membentuk karakter dasar yang menjadi penentu karakternya ke depan, oleh karena itu pendidikan di dalam keluarga merupakan salah satu organ penting yang digalakkan Gülen.

Selain pendidikan di dalam keluarga, Gülen juga membentuk lembaga pendidikan yang berfungsi sebagai sarana pencarian ilmu pengetahuan dan pengembangan bahasa. Melalui institusi pendidikan yang dibentuknya, ia ingin melahirkan generasi-genarasi muda yang tidak hanya cakap dalam agama tetapi juga memiliki pengetahuan yang luas dalam sains. Satu hal yang menarik dari pemikiran Gülen mengenai pendidikan, ia mengatakan bahwa "pendidikan itu tidak sama dengan pengajaran, setiap orang dapat mengajar, tetapi hanya sedikit yang bisa mendidik." 25

Pendidikan menurut pandangan Gülen harus memiliki beberapa kebaikan antara lain, (1) pendidik harus memperhatikan dengan sungguh-sungguh kepada semua aspek dari pikiran, ruh, dan diri seseorang, serta mengangkatnya ke derajat kesempurnaan yang se-

${ }^{25}$ Ali Unal dan Alphonse Williams, Advocate of Dialogue: Fethullah Gülen. 2000, Fairfax: The Fount ain, h.309-315. pantasnya; (2) sebuah sistem pendidikan dinilai berdasarkan universalitasnya, kelengkapannya, dan kualitas dari murid-muridnya. ${ }^{26}$

Pendidikan yang digagas oleh Gülen juga memiliki landasan Tasawuf yang kental. Ia mengenalkan kepada murid-muridnya untuk selalu menanamkan cinta, iman, dan Sunnah Nabi dalam setiap prilaku. Ia mengajarkan kepada murid-muridnya untuk selalu menyucikan diri, menerapkan prinsip dasar hizmet, yaitu melayani masyarakat dan selalu menerapkan konsep dasar dalam Tasawwuf yaitu taqwa, taubat, zuhud, ikhlas, muraqaba, istiqamah, tawakkal, tawadu',syukur, ihsan, sabar, dan ma'r ifah.

Cinta adalah elemen terpenting dalam diri setiap makhluk hidup. Menurut Gülen, cinta terhadap Ilahi dapat memunculkan semangat humanistik dalam bentuk cinta kepada sesama manusia dan penghargaan terhadap nilai-nilai perbedaan diantara sesama manusia. Cinta inilah yang mucul juga dari pandangan Jalaludin Rumi yang mengembangkan definisi cinta melalui pendekatan cinta sufistik. Melalui pendekatan Cinta ilahi inilah Gülen berupaya mengharmonisasikan para pemeluk agama untuk saling menghargai dan menentang keras setiap tindakan kekerasan, meliputi prilaku terorisme yang mengatasnamakan agama.

Iman adalah elemen penting lainnya, setiap orang yang memiliki iman akan mampu menemukan jalan pengabdian kepada yang maha kuasa. Gülen mengembangkan pendidikan me-

${ }^{26}$ M. Fethullah Gülen. "Muhammad Sebagai Pendidik", Fethullah Gülen Chair Bulletin, edisi Mei, Juni, juli 2011, h. 07-08. 
lalui upaya penyeimbangan unsur spiritual dan unsur material. Gülen menganggap harmonisasi antara modernitas dan spiritualitas disertai dengan semangat untuk melayani masyarakat. Gülen menyadari bahwa problem umat muslim saat ini bersumber dari pola pikir materialis sehingga mengakibatkan terdegradasinya nilai-nilai spiritual dalam kehidupan. Ia percaya bahwa harmonisasi, damai dengan alam, sesama manusia, dan dalam diri manusia itu sendiri hanya bisa dicapai melalui rekonsiliasi antara unsur material dan spiritual. ${ }^{27}$

Begitu pula dengan Sunnah Nabi, perjalanan spritual juga harus didukung oleh landasan yang jelas yaitu sunnah Rasulullah meliputi pengaplikasian metode pendidikan zaman Rasulullah yang masih relevan untuk dikembangkan di masa sekarang, seperti ajaran Rasulullah kepada manusia tentang upaya mencari pencapaian tertinggi, sama seperti yang dilakukan oleh para sahabat untuk mencapai kesempurnaan moral dan spiritual yaitu melalui pendidikan yang diberikan Rasulullah. ${ }^{28}$

\section{Penutup}

Dari uraian di atas terlihat jelas, bagaimana Gulen mentransformasikan ajaran tasawuf ke dalam bentuk aksi yang nyata, yang langsung menyentuh persoalan penting umat Islam, dan masyarakat dunia pada umumnya.

Ia mengkontekstualisasikan ajaran tasawuf ke dalam realitas demi menghasilkan generasi-generasi yang disebutnya dengan 'the golden genera-

${ }^{27}$ Ali Unal dan Alphonse Williams, Advocate, h. 241.

28Ibid. tion" dan sekaligus mewujudkan perdamaian abadi di bumi ini. []

\section{DAFTAR PUSTAKA}

Abdullah, M. Amin, Muslim-Christian Relations: Reinventing the Common Ground to Sustain a Peaceful Coexistence in the Global Era. Draft paper yang disampaikan di the International Seminar on "The Vision of Fethullah Gulen and Muslim-Christian Relations", St. Patrick's Campus, Australian Catholic Uni-versity, Melbourne, Australia, 15-16 Juli 2009.

Gülen, Fethullah, "Muhammad Sebagai Pendidik", Fethullah Gülen Chair Bulletin, edisi Mei, Juni, juli 2011.

Gülen, Fethullah, Towards a Global Civilization of Love and Tolerance, Clifton: Light Publications, 2004.

Haq, Muhammad Zaairul, Jalaluddin Rumi: Terbang menuju Keabadian Cinta hingga Makna dibalik Kisah, Sidorejo: Kreasi Wacana, 2011.

Khamami, A. Rizqon Khamami, "Islam Kosmo-politan Dalam Ajaran-ajaran Fethullah Gülen", Jurnal Al-Fikr, Volume 15 Nomor 2 Tahun 2011.

Sahin, Ali, Pemikiran M. Fethullah Gulen Dalam Pendidikan Islam, Skripsi pada Jurusan Pendidikan Agama Islam FITK UIN Syarif Hidayatullah Jakarta, 2014.

Unal, Ali, dan Alphonse Williams, Advocate of Dialogue: Fethullah Gulen, Fairfax: The Fountain, 2000.

Unsal, Ali, "Model Pendidikan Gulen", makalah disampaikan di International Conferen-ce on Indonesian Studies, Bali, 9 Pebruari 2012.

Yavuz and Esposito, Turkish Islam and the Secular State: the Gulen Movement. Edited by M. H. Yavuz and J. L. Esposito Syracuse: Syracuse University Press.

Yilmaz, "State, Law, Civil Society, and Islam in Contemporary Society". The Muslim World 95. 
Yilmaz, Ihsan, "Tajdid For Coexistence: Social Innovation And Activism Socio-Cultural Initiatives For Peace From Rumi and Gülen ," dalam Peaceful Coexistence: Fethullah Gülen 's Initiatives in the Contemporary World, New Jersey: TUGHRAH BOOKS, 2009.

Yucel, Salih Yucel, "Fethullah Gulen: Spiritual Leader in a Global Islamic Context", Journal of Religion \& Society, The Kripke Center. Volume 12 (2010). 